\title{
Pengaruh Lama Penyimpanan Semen Segar pada Media Simpan Coldbox terhadap Motilitas, Viabilitas Spermatozoa dan $\mathrm{pH}$ Semen Ayam Buras
}

\author{
Alfonsius Bria ${ }^{\mathrm{a}}$, Agustinus A. Dethan ${ }^{\mathrm{b}}$ dan Charles V. Lisnahan ${ }^{\mathrm{c}}$ \\ ${ }^{a}$ Fakultas Pertanian, Universitas Timor, Kefamenanu, TTU - NTT, 8563, Indonesia, email: alfonsiusbria22@ gmail.com \\ ${ }^{b}$ Fakultas Pertanian, Universitas Timor, Kefamenanu, TTU - NTT, 8563, Indonesia, email: dethanagung15@ gmail.com \\ cFakultas Pertanian, Universitas Timor, Kefamenanu, TTU - NTT, 8563, Indonesia, email: charleslisnahan03@ gmail.com
}

\section{Article Info}

Article history:

Received 23 Juni 2021

Received in revised form 11 Juli 202

Accepted 30 Juli 2021

DOI

https://doi.org/10.32938/ja.v6i3.1401

Keywords:

Ayam Buras

Semen

Coldbox

Motilitas

Viabilitas Spermatozoa

pH Semen.

\section{Abstrak}

Tujuan dari penelitian ini adalah untuk mengetahui pengaruh lama penyimpanan semen segar pada media coldbox terhadap motilitas, viabilitas spermatozoa dan $\mathrm{pH}$ semen ayam buras. Penelitian ini dilaksanakan pada Bulan Oktober 2020 di Laboratorium Fakulta Pertanian Universitas Timor Kefamenanu Kabupaten Timor Tengah Utara (TTU). Semen ayam yang digunakan dalam penelitian ini berasal dari 10 ekor ayam buras jantan dengan kisaran umur 2-3 tahun atau dengan panjang taji 2-3 cm. Hal ini sebagai dasar seleks ternak jantan untuk menghasilkan semen yang berkualitas yang akan dijadikan sebagai bahan penelitian. Penelitian ini menggunakan metode experimen laboratorium dengan rancangan acak lengkap (RAL) yang terdiri dari 4 perlakuan dan 3 ulangan sehingga terdapat 12 unit percobaan yaitu: R1: Penyimpanan semen segar selama waktu (0 jam), R2. Penyimpanan semen segar selama waktu (2 jam), R3: Penyimpanan semen segar selama waktu (4 jam), R4: Penyimpanan semen segar selama waktu (6 jam). Variabel yang digunakan dalam penelitian ini adalah: Motilitas spermatozoa, Viabilitas spermatozoa, pH semen. Data yang diperoleh dianalisis menggunakan Analisi Sidik Ragam uji Duncan. Dengan menggunakan software statistical packge for the social ssciences (SPSS. 20). Hasil penelitian menunjukkan bahwa rata-rata motilitas spermatozoa pada perlakuan R1, R2, R3 dan R4, masing-masing adalah motilitas massa $4 \pm 0$, $4 \pm 0,4 \pm 0$ dan $3 \pm 0,6$. Motilitas individu $80 \pm 00,80 \pm 00,80 \pm 00$, dan $80 \pm 00$. Viabilitas $96 \pm 02,94 \pm 04,95 \pm 73$, dan $91 \pm 75$. pH semen $8 \pm 05$, $8 \pm 00,8 \pm 05$ dan $8 \pm 00$. Analisis statistik menunjukan bahwa perlakuan berpengaruh nyata pada viabilitas spermatozoa ayam buras. Disimpulkan bahwa spermatozoa ayam buras dapat bertahan hidup selama 6 jam di dalam media simpan coldbox yang berisi es batu.

\section{Pendahuluan}

Ayam buras adalah ayam yang biasa dikenal dengan sebutan ayam kampung oleh masyarakat Indonesia. Ayam ini dapat diindikasikan dari hasil domestikasi dari ayam hutan. Sebelumnya ayam tersebut hidup di hutan, kemudian didomestikasi serta dikembangkan dan dibudidayakan oleh masyarakat pedesaan (Yaman, 2010).

Masyarakat Nusa Tenggara Timur atau Indonesia bagian Timur seluruhnya lebih dominan membudidayakan ayam buras karena perawatannya mudah, daya tahan hidupnya cukup tinggi, adaptasi dengan lingkungan, dan konsumsi pakan yang mudah didapatkan serta digemari masyarakat karena baik daging maupun telurnya memiliki cita rasa yang lebih baik dibandingkan dengan ayam lainnya, sehingga perlu adanya peningkatan pengetahuan peternak untuk memperbaiki mutu genetik dalam kinerja reproduksi ternak agar mampu mengasilkan ternak yang lebih baik/unggul.

Kemampuan kinerja reproduksi ternak dipengaruhi oleh beberapa faktor yaitu kualitas spermatozoa, daya tahan spermatozoa hidup dalam mempertahankan kualitas spermatozoa dan keterampilan inseminator dalam melakukan Insiminasi Buatan (IB) pada ternak ayam. Kualitas spermatozoa dikatakan baik jika memiliki jumlah spermatozoa hidup tinggi dan spermatozoa mati $<15 \%$, (Bintara, 2011). Kualitas dan kuantitas sperma yang menurun akan memperkecil angka konsepsi yang dicapai (Hafez 1993).

Salah satu cara dalam mempertahankan kualitas dan kuantitas spermatozoa, perlu adanya tempat penyimpanan semen segar setelah ditampung dari ternak jantan. Tempat penyimpanan yang dapat digunakan adalah media simpan dingin (coldbox) yang di isi dengan es batu. Hardjopranjoto (1976) Tujuan menggunakan es batu yakni untuk menghambat aktivitas metabolisme baik secara fisik maupun secara kimia dalam kecepatan yang rendah dan Wills et al. (1998) juga menyatakan bahwa Tujuan dari penyimpanan pada suhu rendah adalah untuk memperpanjang masa kesegaran suatu produk untuk mempertahankan mutu.

Media simpan dingin (Coldbox) merupakan salah satu wadah penyimpanan untuk mempertahankan kualitas spermatozoa dalam waktu penyimpanan yang panjang dengan harapan kualitas bahan yang disimpan tetap segar, tetap terjaga dan bertahan lebih lama bila dipindahkan dari satu tempat ke tempat lain dan menjaga kualitas hingga sampai di tempat tujuan.

Berdasarkan uraian dalam latar belakang tersebut maka perlu dilakukan penelitian dengan Judul: Pengaruh lama penyimpanan semen segar pada media simpan coldbox terhadap motilitas, viabilitas spermatozoa dan $\mathrm{pH}$ semen ayam buras. Rumusan masalah bagaimana Pengaruh lama penyimpanan semen segar pada media simpan coldbox terhadap motilitas, viabilitas spermatozoa dan $\mathrm{pH}$ semen ayam buras. Tujuan penelitian dari penelitian ini adalah untuk mengetahui pengaruh lama penyimpanan semen segar pada media coldbox terhadap motilitas, viabilitas spermatozoa dan $\mathrm{pH}$ semen ayam buras. Manfaat penelitian ini adalah sebagai informasi bagi peternak dalam penyimpanan semen segar dan pengembangan ilmu pengetahuan khususnya mengenai penanganan semen segar ayam buras.

\section{MATERI DAN METODE}

\subsection{Waktu Dan Tempat Penelitian}

Penelitian ini dilaksanakan pada Bulan Oktober 2020 di Laboratorium Fakultas Pertanian Universitas Timor Kefamenanu Kabupaten Timor Tengah Utara (TTU).

\subsection{Materi Penelitian}

Semen ayam yang digunakan dalam penelitian ini berasal dari 10 ekor ayam buras jantan dengan kisaran umur 2-3 tahun atau dengan panjang taji 2-3 $\mathrm{cm}$. Hal ini sebagai dasar seleksi ternak jantan untuk menghasilkan semen yang berkualitas yang akan dijadikan sebagai bahan penelitian.

\subsubsection{Bahan dan Alat}

Bahan-bahan yang digunakan dalam penelitian ini adalah es batu, semen segar, larutan eosin $0,2 \%$, kertas indikator $\mathrm{pH}$, kertas tissue, alkohol $70 \%$, dan aquades.

Alat-alat yang digunakan untuk pengambilan semen meliputi: pipet tetes, tabung penampung semen berskala, coldbox, mikroskop, gelas objek, gelas penutup, termometer, hemositometer, alat hitung menual (hand tally counter) dan lampu spritus.

\subsubsection{Metode Penelitian}

Penelitian ini menggunakan metode experimen laboratorium dengan rancangan acak lengkap (RAL) yang terdiri dari 4 perlakuan dan 3 ulangan sehingga terdapat 12 unit percobaan yaitu:

$\mathrm{R}_{1}$ : Penyimpanan semen segar selama waktu ( 0 jam)

$\mathrm{R}_{2}$ : Penyimpanan semen segar selama waktu ( 2 jam)

$\mathrm{R}_{3}$ : Penyimpanan semen segar selama waktu (4 jam)

$\mathrm{R}_{4}$ : Penyimpanan semen segar selama waktu (6 jam)

\subsection{Variabel Penelitian}

Variabel yang digunakan dalam penelitian ini adalah:

1. Motilitas spermatozoa

2. Viabilitas spermatozoa

3. $\mathrm{pH}$ semen

\subsection{Tahap Persiapan Ternak}

Ternak ayam buras jantan yang digunakan dalam penelitian ini dapa dikandangkan selama 2 (dua) minggu sebelum melakukan penampungan semen dan diberi pakan yang berkualitas dengan tujuan ternak jantan dapat menghasilkan kualitas spermatozoa yang baik dan tidak liar saat melakukan penampungan semen.

\subsection{Tahap Penampungan Semen}

Pada tahap ini dapat dilakukan penampungan semen ayam dengan menggunakan metode pengurutan/massage pada bagian punggung ayam. pengurutan dilakukan dari muka ke belakang sambil mengangkat ekor dan mengadakan sedikit tekanan pada bagian akhir phalus ini dilakukan dengan tujuan untuk menimbulkan refleks ejakulatoris. Penampungan akan dilakukan dua orang, satunya memegang ayam dan satunya melakukan pengurutan untuk mengeluarkan semen dari alat kelamin ayam sekaligus menampungnya dengan menggunakan tabung penampung

\subsection{Tahap Evaluasi Semen Segar Setelah Penampungan}

Evaluasi atau pemeriksaan semen merupakan suatu tindakan yang perlu dilakukan untuk melihat kuantitas (jumlah) dan kualitas semen. Pemeriksaan semen dibagi menjadi dua kelompok, yaitu pemeriksaan secara makroskopis dan pemeriksaan mikroskopis. Pemeriksaan secara makroskopis meliputi volume, $\mathrm{pH}$, warna, bau, konsntrasi spermatozoa, sedangkan pemeriksaan mikroskopis meliputi motilitas, viabilitas spermatozoa, dan $\mathrm{pH}$ semen. Standar penilaian konsentrasi 500 - 1000 juta sel sperma dengan persentase motilitas individu $70 \%$ yang memenuhi syarat untuk diberi perlakuan. 


\subsection{Evaluasi Semen Secara Makroskopis}

Volume ejakulasi yaitu jumlah $\mathrm{ml}$ semen setiap ejakulasi dapat dilihat langsung pada skala tabung penampung.

Derajat keasaman $(\mathrm{pH})$ semen perlu diukur untuk memastikan bahwa cairan semen hasil penampungan memiliki karakteristik yang normal. Evaluasi $\mathrm{pH}$ semen dapat dilakukan dengan menggunakan kertas indikator $\mathrm{pH}$.

Caranya: kertas indikator dicelup dalam setetes semen kemudian kertas indikator akan mengalami perubahan warna selanjutnya disesuaikan dengan warna tersebut dengan warna pada kemasan kertas indikator.

Warna semen dapat diamati langsung karena tabung penampung semen terbuat dari gelas atau plastik tembus pandang. Semen ayam umumnya berwarna seperti air susu, warna kemerahan merupakan tanda bahwa semen kontraminasi oleh dara segar, sedangkan apabila warnanya mendekati coklat merupakan tanda bahwa darah yang mengontraminasi semen sudah mengalami dekomposisi. Warna kehijauan merupakan tanda adanya bakteri pembusuk.

Bau dapat langsung dicium dengan cara lewatkan penampung semen di bawah lubang hidung. Semen yang normal pada umumnya, memiliki bau amis khas hewan itu sendiri. Bau busuk bisa terjadi apabila semen mengandung nanah yang disebabkan infeksi organ atau saluran reproduksi hewan jantan.

Kekentalan atau konsistensi merupakan salah satu sifat semen yang memiliki kaitan dengan kepadatan/kosentrasi sperma di dalamnya, tabung penampung semen dimiringkan secara perlahan ke kiri atau ke kanan dan diamati gerakan semen di dalam tabung perpindahan semen yang lambat menandakan semen tersebut cukup kental. Semakin kental semen dapat diartikan bahwa semakin tinggi konsentrasi spermanya.

\subsection{Evaluasi Semen Secara Mikroskopis}

\section{a). Motilitas spermatozoa}

Motilitas massa spermatozoa diamati sesuai petunjuk Dethan et al (2010), yaitu dengan cara meletakkan semen sebanyak satu tetes di atas objek glass tanpa ditutup cover glass kemudian diamati di bawah mikroskop perbesaran 100 kali.

Kualitas semen dapat ditentukan berdasarkan penilaian gerakan massa adalah sebagai berikut:

4 Sangat baik (+++) jika gerakan spermartozoa terlihat membentuk gelombang-gelombang besar, banyak, gelap, tebal dan aktif serta bergerak cepat berpindah-pindah tempat

3 Baik (++) bila gerakan spermatozoa terlihat seperti gelombanggelombang kecil,tipis, jarang, kurang jelas dan bergerak lamban

2 Cukup (+) bila tidak terlihat gerakan spermatozoa seprti gelombang tapi hanya terlihat gerakan individual aktif progresif.

1 Buruk (Necrospermia, 0) jika hanya sedikit atau tidak terlihat gerakan individual spermatozoa sama sekali.

Motilitas individu spermatozoa diamati dengan mengambil satu tetes semen dan diletakkan di atas objek glass dan ditutup dengan cover glass kemudian diamati di bawah mikroskop dengan perbesaran 400 kali. Motilitas individual yang normal adalah minimal motilitasnya $70 \%$.

Berdasarkan motilitas individual, maka penilaian terhadap kualitas spermatozoa adalah dengan skor $0-5$ sebagai berikut:

5 jika gerakan spermatozoa yang sangat progresif, membentuk gelombang yang sangat cepat dan menunjukkan $100 \%$ sperma motil.

4 jika spermatozoa bergerak secara progresif dan membentuk gelombang dengan $90 \%$ spermatozoa motil

3 jika 50\% -80\% spermatozoa bergerak progresif dan menghasilkan gerakan massa

2 jika gerakan spermatozoa melingkar, kurang dari $50 \%$ bergerak progresif dan tidak ada gelombang

1 jika gerakan spermatozoa berputar di tempat

0 jika spermatozoa imotil atau tidak bergerak

b). Viabilitas spermatozoa (\%)

Viabilitas dapat dimatikan dengan pembuatan preparat ulas. Preparat ulas dapat dibuat dengan cara meneteskan satu tetes semen diatas gelas objek yang disediakan kemudian ditambahkan satu tetes larutan eosin. Setelah itu gunakan gelas objek lain dapat ditarik kearah lain membentuk sedut $45^{\circ} \mathrm{C}$. setelah itu keringkan preparat ulas dan diamati menggunakan mikroskop dengan pembesaran 400 kali. Viabilitas dapat dihitung dengan menghitung spermatozoa yang hidup karena tidak menyerap warna sedangkan yang mati dapat menyerap warna (Susilawati, 2011). Persamaan untuk menghitung viabilitas:

$$
\text { Viabilitas (\%) }=\frac{\text { Jumlah spermatozoa yang hidup }}{\text { Jumlah sepermatozoa yang dihitung }} \times 100
$$

\subsection{Tahap Perlakuan}

Setelah semennya ditampung dari ternak jantan dimasukkan ke dalam tabung sesuai dengan perlakuan yang dikenakan, kemudian disimpan dalam coldbox yang berisi es batu dengan suhu dalam coldbox $\pm 5^{\circ} \mathrm{C}$. Tujuan menggunakan es batu yakni untuk penghambatan aktivitas metabolisme baik secara fisik maupun kimia dalam kecepatan yang rendah (Hardjopranjoto, 1976; Hardijanto, 1991).

\subsection{Tahap Pengambilan Data}

Evaluasi semen sesuai waktu lama simpan yakni 0 jam, 2 jam, 4 jam dan 6 jam sesuai variabel yang diteliti.

\subsection{Analisis Data}

Data yang diperoleh dianalisis menggunakan Analisis Sidik Ragam atau analysis of variance (ANOVA). Apabila hasil analisis sidik ragaman menunjukkan pengaruh perlakuan berbeda nyata $(\mathrm{P}<0,5)$ maka dilanjutkan dengan uji jarak berganda Duncan menurut petunjuk Steel dan Torrie (1991). Dengan menggunakan software statistical packge for the social sciences (SPSS. 20).

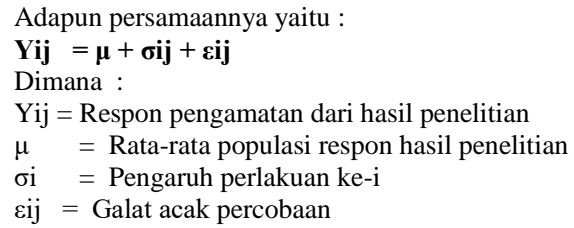

\section{HASIL DAN PEMBAHASAN}

\subsection{Gambaran Umum Penelitian}

Ayam yang diambil semen dalam keadaan sehat dan lingkungan turut menunjang dalam proses penelitian. Setelah semen ditampung dan dievaluasi, hasil evaluasi menunjukkan semen tersebut layak untuk digunakan kemudian dikenakan perlakuan sesuai dengan metode yang digunakan serta pengambilan data dilakukan hingga akhir penelitian ini. Data awal evaluasi semen dapat dilihat pada Table 1 .

Table 1. Evaluasi semen secara makroskopis dan mikroskopis

\begin{tabular}{|c|c|c|}
\hline No & Uraian & Hasil \\
\hline 1 & Volume (ml) & 0,3 \\
\hline 2 & Warna & Putih susu \\
\hline 3 & $\mathrm{Bau}$ & Khas semen ayam \\
\hline 4 & $\mathrm{Ph}$ & 8,8 \\
\hline 5 & Konsistensi/kekentalan & Kental \\
\hline 6 & Motilitas massa & +++ \\
\hline 7 & Motilitas mindividu (\%) & $80 \%$ \\
\hline 8 & Konsentrasi (juta/ml) & $13,6 \times 10^{10}$ \\
\hline 9 & Viabilitas spermatozoa (\%) & $97 \%$ \\
\hline
\end{tabular}

Hasil evaluasi semen segar secara makroskopis dan mikroskopis menunjukan bahwa semen segar ayam buras ini layak digunakan sebagai bahan penelitian.

\subsection{Pengaruh Perlakuan terhadap Motilitas Massa Spermatozoa Ayam Buras}

\subsubsection{Motilitas Massa}

Gerakan massa spermatozoa merupakan cermin dari gerakan individu spermatozoa. Hal ini sesuai pendapat Mardalestari (2005) bahwa gerakan massa spermatozoa mencerminkan gerakan individu spermatozoa. Semakin aktif dan semakin banyak spermatozoa yang bergerak, maka gerakan massapun semakin bagus(semakin tebal dan pergerakannya semakin cepat). Gerakan massa yang diperoleh dalam penelitian ini dapat dilihat pada Tabel 2.

Tabel 2. Rataan motilitas massa spermatozoa pada perlakuan

\begin{tabular}{ccccc}
\hline & \multicolumn{4}{c}{ Perlakuan } \\
\cline { 2 - 5 } Ulangan & $\mathrm{R}_{1}$ & $\mathrm{R}_{2}$ & $\mathrm{R}_{3}$ & $\mathrm{R}_{4}$ \\
(0 Jam) & (2 Jam) & (6 Jam) \\
\hline 1 & 4 & 4 & 4 & 4 \\
2 & 4 & 4 & 4 & 3 \\
3 & 4 & 4 & 4 & 3 \\
\hline Jumlah & 12 & 12 & 12 & 10 \\
Rataan & $4 \pm 0$ & $4 \pm 0$ & $4 \pm 0$ & $3 \pm 0,6$ \\
\hline
\end{tabular}

Keterangan: 4: (+++), (3: (++) NS (Non Signifikan)

Hasil analisis statistik menunjukkan bahwa rataan persentase spermatozoa hidup atau gerakan massa spermatozoa yang diamati dan disimpan pada media coldbox dengan suhu $5^{\circ} \mathrm{C}$ menunjukkan kualitas semen dengan kategori sangat baik. Analisis statistik pada Tabel 1 menunjukan pengaruh perlakuan berbeda tidak nyata. Kesamaan nilai rataan ini menunjukkan bahwa spermatozoa sanggup bertahan hidup dalam coldbox yang di beri es batu selama 6 jam. Menurut Toelihere (1993), jika waktu penyimpanan semen semakin lama maka akan terjadi perubahan

integrasi membran sel berupa pembengkakan pada daerah akrosom dari spermatozoa. Fungsi akrosom dalam proses fertilisasi sangat penting karena menghasilkan enzim hyaluronidase yang penting untuk penerobosan ovum.

Hasil penelitian ini menunjukkan bahwa coldbox yang terisi es batu dapat digunakan sebagai media simpan semen segar selama 6 jam sebelum semen segar tersebut digunakan. Hal ini sesuai dengan pendapat Nalbandov (1990) menyatakan bahwa penyimpanan semen ayam pada suhu $4^{0} \mathrm{C}$ dapat mempertahankan daya hidup sperma dalam beberapa hari tapi mulai kehilangan fertilitasnya dalam 48 jam. Mata Hine et al. (2014), menyatakan bahwa daya 
tahan hidup spermatozoa adalah kemampuan spermatozoa untuk tetap bergerak dalam kurun waktu tertentu setelah penyimpanan in vitro.

\subsubsection{Motilitas Individu}

Gerakan individu merupakan salah satu parameter untuk melihat motilitas spermatozoa. Motilitas individu merupakan daya gerak spermatozoa yang digunakan sebagai ukuran kemampuan spermatozoa untuk membuahi sel telur. Daya gerak maju ini sangat diperlukan pada saat berada di dalam saluran kelamin betina untuk mencapai tempat terjadinya fertilisasi (Danang et al., 2012). Pengujian motilitas spermatozoa merupakan satu parameter penting (patokan) yang dapat dijadikan dasar informasi penilaian untuk Insiminasi Buatan (IB). Gerakan individu spermatozoa yang diperoleh dalam penelitian ini dapat dilihat pada Tabel 3 .

Tabel 3. Pengaruh perlakuan terhadap motilitas individu spermatozoa

\begin{tabular}{ccccc}
\hline & \multicolumn{4}{c}{ Perlakuan } \\
\cline { 2 - 5 } Ulangan & $\begin{array}{c}\mathrm{R}_{1} \\
(0 \mathrm{Jam})\end{array}$ & $\begin{array}{c}\mathrm{R}_{2} \\
(2 \mathrm{Jam})\end{array}$ & $\begin{array}{c}\mathrm{R}_{3} \\
(4 \mathrm{Jam})\end{array}$ & $\begin{array}{c}\mathrm{R}_{4} \\
(6 \mathrm{Jam})\end{array}$ \\
\hline 1 & 80 & 80 & 80 & 80 \\
2 & 80 & 80 & 80 & 80 \\
3 & 80 & 80 & 80 & 80 \\
\hline Jumlah & 240 & 240 & 240 & 240 \\
Rataan & $80 \pm 00$ & $80 \pm 00$ & $80 \pm 00$ & $80 \pm 00$ \\
\hline
\end{tabular}

Keterangan: NS (Non Signifikan)

Hasil analisis statistik menunjukkan bahwa rataan pergerakan individu spermatozoa yang diamati dengan menggunakan media simpan coldbox dengan suhu $5^{\circ} \mathrm{C}$ dalam waktu yang berbeda menunjukkan kualitas semen yang termasuk dalam kategori sangat baik atau normal yaitu $80 \%$.

Analisi statistik menunjukkan bahwa pengaruh perlakuan berbeda tidak nyata. Hal ini karena kondisi ruang media coldbox memungkinkan untuk spermatozoa dapat hidup lebih lama yakni sampai 6 jam. Hafez (1993) menyatakan bahwa unggas yang normal mempunyai motilitas individu antara 60-80\%. Motilitas yang baik dapat memungkinkan sel spermatozoa dapat mencapai sel telur di dalam saluran oviduk dalam waktu yang relatif singkat, sehingga memungkinkan terjadinya pembuahan yang sempurna. Dumpala $e$ al., (2006) menyatakan bahwa motilitas individu berada dalam kisaran yang normal yaitu di atas $70 \%$. Tingkat motilitas $80 \%$ masih dapat dinilai baik sebagaimana dilaporkan Garner dan Hafez (2000) yakni berkisar antara 60 $80 \%$.

Menurut Nurfirman (2001), standar balai inseminasi buatan lembang motilitas individu di atas 40\% masih layak digunakan untuk Insiminasi Buatan (IB). Sexton dan Giesen (1982), Howarth. (1983), Bootwalla dan Miles (1992), menyatakan bahwa jika metabolisme spermatozoa menghasilkan asam laktat, maka angka keasaman merupakan salah satu faktor yang dapat menurunkan motilitas dan viabilitas spermatozoa. Bearden dan Fuquay (1984) yang disitasi Syafar. (2001) menjelaskan bahwa spermatozoa motil tergolong normal dan fertil pada $50-80 \%$.

\subsection{Pengaruh Perlakuan Terhadap Viabilitas Spermatozoa Ayam Buras}

Viabilitas Spermatozoa adalah kemampuan spermatozoa untuk tetap bertahan hidup sejak awal penyimpanan hingga spermatozoa mati, dengan batasan bahwa spermatozoa yang hidup tidak menyerap warna pada bagian kepalanya, sedangkan spermatozoa yang mati akan menyerap warna karena permeabilitas dinding meningkat. Perbedaan afinitas zat warna antara sel-sel sperma yang mati dan yang hidup digunakan untuk menghitung jumlah sperma hidup secara objektif, (Cheesbrough, 2006). Presentase jumlah spermatozoa hidup dalam penelitian ini dapat dilihat pada Tabel 4.

Tabel 4. Rataan viabilitas spermatozoa pada perlakuan lama simpan

\begin{tabular}{lllll}
\hline & Perlakuan & & \\
\cline { 2 - 5 } Ulangan & $\mathrm{R}_{1}$ & $\mathrm{R}_{2}$ & $\mathrm{R}_{3}$ & $\mathrm{R}_{4}$ \\
(0 Jam) & (2 Jam) & (6 Jam) $)$ & 89.5 \\
\hline 1 & 94 & 96 & 94.5 & 93 \\
2 & 98 & 94 & 94.5 & 91,5 \\
3 & 96,5 & 94,5 & 97,5 & 274,0 \\
Jumlah & 288,5 & 284,5 & 286,5 & $91 \pm 75^{\mathrm{b}}$ \\
Rataan & $96 \pm 02^{\mathrm{a}}$ & $94 \pm 04^{\mathrm{a}}$ & $95 \pm 73^{\mathrm{a}}$ &
\end{tabular}

Keterangan: $(a, b)$ Signifikan

Hasil analisis statistik menunjukkan bahwa pengaruh perlakuan berbeda nyata $(\mathrm{P}<0,05)$ terhadap motilitas spermatozoa. Hasil penelitian ini menunjukkan bahwa semakin lama waktu simpan semen segar di dalam coldbox akan mengalami penurunan jumlah spermatozoa hidup. Namun, penurunan persentase viabilitas spermatozoa pada penelitian ini hanya $5,20 \%$ yakni pada lama simpan 6 jam (R4) $91 \pm 75$. Salah satu upaya untuk mempertahankan daya fertilitas yang optimum bisa dilakukan dengan jalan penyimpanan semen pada suhu 4 sampai $5^{\circ} \mathrm{C}$ dengan maksud penghambatan terhadap aktivitas metabolisme baik secara fisik maupun kimia (Danang et al., 2012).

Penyimpanan semen yang lebih lama akan semakin meningkatkan tingkat kematian spermatozoa karena rusaknya membran plasma yang berakibat pada terganggunya suplai energi spermatozoa sehingga menurunkan motilitas spermatozoa. Jumlah spermatozoa yang mati akan memengaruhi spermatozoa yang masih hidup selama proses penyimpanan (Solihati et al., 2006). Hal ini sejalan dengan pendapat Purwanti. (2006) dalam Johari et al. (2009) bahwa daya hidup spermatozoa di luar tubuh yang rendah akan mudah sekali mengalami kematian. Penurunan viabilitas spermatozoa juga dapat disebabkan stress oksidatif yang dialami spermatozoa selama penyimpanan pada suhu dingin. Hal ini sesuai pendapat Susilawati. (2011), bahwa proses pendinginan mengakibatkan stress fisik dan kimia pada membrane sel yang dapat menurunkan viabilitas spermatozoa.

\subsection{Pengaruh perlakuan terhadap $\mathrm{pH}$ semen ayam buras}

Derajat keasaman $(\mathrm{pH})$ adalah suatu ukuran yang menguraikan derajat tingkat keasaman atau kadar alkali dari suatu larutan, $\mathrm{pH}$ diukur pada skala 0 14 (Nogroho, 2016). Derajat keasaman (pH) semen perlu diukur untuk memastikan bahwa cairan semen hasil penampungan memiliki karakteristik yang normal atau tidak. Derajat keasaman $(\mathrm{pH})$ yang diperoleh dalam penelitian ini dapat dilihat pada Tabel 5 .

Tabel 5. Rataan derajat keasaman $(\mathrm{pH})$ semen dari perlakuan

\begin{tabular}{ccccc}
\hline Ulangan & \multicolumn{4}{c}{ Perlakuan } \\
\cline { 2 - 5 } & $\begin{array}{c}\mathrm{R}_{1} \\
\text { (0 Jam) }\end{array}$ & $\begin{array}{c}\mathrm{R}_{2} \\
\text { (2 Jam) }\end{array}$ & $\begin{array}{c}\mathrm{R}_{3} \\
\text { (4 Jam) }\end{array}$ & $\begin{array}{c}\mathrm{R}_{4} \\
\text { (6 Jam) }\end{array}$ \\
\hline 1 & 8,8 & 8,8 & 8,8 & 8,7 \\
2 & 8,8 & 8,8 & 8,7 & 8,7 \\
3 & 8,7 & 8,8 & 8,8 & 8,7 \\
\hline Jumlah & 26,30 & 26,40 & 26,30 & 26,10 \\
Rataan & $8 \pm 06$ & $8 \pm 00$ & $8 \pm 06$ & $8 \pm 00$ \\
\hline
\end{tabular}

Keterangan: NS (Non Signifikan)

Hasil analisis statistik menunjukkan bahwa rataan derajat keasaman $(\mathrm{pH})$ semen pengaruh berbeda tidak nyata. Hasil penelitian ini menunjukan $\mathrm{pH}$ semen masih dalam batasan normal dan bersifat basa. Hal ini sesuai pendapat Hardiyanto (1993) bahwa $\mathrm{pH}$ semen ayam kampung bervariasi antara 8,59,0 .

Derajat keasaman $(\mathrm{pH})$ semen sangat berpengaruh terhadap daya hidup spermatozoa. Semakin rendah nilai $\mathrm{pH}$ maka spermatozoa yang hidup akan semakin rendah. Nilai $\mathrm{pH}$ dapat menurun selama penyimpanan akibat peninggian suhu dan penambahan waktu (Toelihere, 1993).

Derajat keasaman $(\mathrm{pH})$ dalam penelitian ini terlihat sedikit terjadi penurunan nilai $\mathrm{pH}$ yakni pada perlakuan (R4) 6 jam. Hal ini diduga karena semakin lama waktu simpan semen akan terjadi penimbunan asam laktat yang dihasilkan oleh spermatozoa itu sendiri. Penguraian fruktosa menyebabkan terbentuknya asam laktat pada semen (Salisbury dan Vandemark, 1985) Semakin banyak asam laktat yang terbentuk maka pH semen akan mengalami penurunan yang significant dan spermatozoa akan banyak yang mati.

\section{KESIMPULAN DAN SARAN}

\subsection{Kesimpulan}

Berdasarkan hasil penelitian ini maka dapat disimpulkan bahwa spermatozoa ayam buras dapat bertahan hidup selama 6 jam di dalam media simpan coldbox yang berisi es batu.

\subsection{Saran}

Perlu adanya penelitian lanjutan dengan lama waktu simpan semen segar di dalam media simpan coldbox lebih dari 6 jam.

\section{DAFTAR PUSTAKA}

Anonimus 2001. Populasi Sapi Bali dan Kebutuhan Daging. http//http://suharjawanasuria.tripod.com/sapi_potong_01. htm. Diakses tanggal 12 november 2011

Bootwalla, S. M. and R.D. Miles RD. 1992. Development of diluents fordomestic fowl semen. World's Poultry Sci. J. 48:121-128 Bearden, H. J. \& Fuquay, J. W. (1984). Applied Animal Reproduction. 2nd edition. Virginia: Reston Publishing Company, Inc.

Bintara, S. 2011. Rasio X:Y dan Kualitas Sperma pada Kambing Kacang dan Peranakan Ettawa. Fakultas Peternakan Universitas Gadjah Madda. Yogyakarta. Sains Peternakaan, 9(2):65-71.

Cheesbrough,M. 2006. Laboratory Practice in Tropical Countries. Cambridge: Cambridge University Press.

Dethan, A. A, Kustono, dan Hari Hartadi. 2010. Kualitas dan Kuantitas Sperma Kambing Bligon Jantan Yang diberi Pakan Rumput Gajah Dengan Suplementasi Tepung Darah. Buletin Peternakan. 34(3) : 145-153

Danang, D. R., N. Isnaini, and P. Trisunuwati. "Pengaruh lama simpan semen terhadap kualitas spermatozoa ayam kampung dalam pengencer ringer's pada suhu 4 C." TERNAK TROPIKA Journal of Tropical Animal Production 13.1 (2012): 47-57.

Dumpala PR, Parker HM, Daniel MC. 2006. The effect of semen storage temperature and diluent type on the sperm quality index of Broiler breeder semen. J Poult Sci 5: 838- 845.

Feradis, 2010. Bioteknologi Reproduksi pada Ternak. Alfabeta. Bandung 
Garner, D. L. and E. S. E. Hafez. 2000. Spermatozoa and Seminal Plasma. In: Reproduction in Farm Animal. 7th ed. Lea and Febringer, Philadelphia. (US): lipincontt Wiliams and Wilkins. P 96-109.

Hafez, E. S. E., 1993. Semen Evaluation. In: Hafez, E. S. E. (Ed.) Reproduction in Farm Animals. 6th ed. Lea \& Febiger, Philadelphia. pp:405-423.

Hardjopranjoto, S. 1976. Ilmu Inseminasi Buatan. Edisi kedua. Fakultas Kedokteran Hewan. Universitas Airlangga. Surabaya.

Hardiyanto, 1993. Pengaruh Semen Ayam Segar Maupun Setelah Diencerkan dan Disimpan Melalui Inseminasi Buatan Terhadap Fertilitas dan Kematian Embrio Telur Ayam Kampung. J. Ilmiah Ilmu- Ilmu Peternakan. 3(4): 47-56

Howarth, B.J.R. 1983. Comparison of diluents for holding cock semen six hours at 41 o C. J. Poultry Sci. 62:1084-1087.

Johari, S., Ondho, Y. S., Wuwuh, S., Henry, Y. B., \& Ratnaningrum, R. (2009, May). Karakteristik Dan Kualitas Semen Berbagai Galur Ayam Kedu (Characteristic and Cemen Quality at Various Lines of Kedu Chicken). In Prosiding Seminar Nasional Kebangkitan Peternakan (pp. 1-16). Fakultas Peternakan Undip.

Mata Hine T, Burhanuddin, Marawali A. 2014. Efektivitas air buah lontar dalam mempertahankan motilitas, viabilitas dan daya tahan hidup spermatozoa sapi bali. Jurnal Veteriner 15 (2) : 263-273.

Mardalestari, R. 2005. Pengaruh Jenis dan Konservasi Krioprotektan serta Metode terhadap Kualitas Semen Beku Ayam Arab (Fayoumi).Skripsi. Program Studi Biologi, Universitas Pakuan, Bogor.

Nalbandov, A. V. 1990. Fisiolog Reproduksi pada mamalia dan unggas. Penerbit Universitas Indonesia Press. Jakarta.

Nogroho, C. (2016). Pengaruh Mengkonsumsi Buah Nanas terhadap pH Saliva pada Santriwati Usia 12- 16 Tahun Pesantren Perguruan Sakahideng Kabupaten Tasikmalaya. Journal ARSA. h. 11

Nurfirman. 2001. Efektifitas Medium Beltsville Poultry Semen Extender (BPSE) terhadap Kualitas Semen Cair Ayam Lokal. http://repository.ipb.ac.id

Salisbury, G.W. dan N. L. Vandemark.1985. Fisiologi Reproduksi dan Inseminasi Buatan pada Sapi. (diterjemahkan oleh: R. Djanuar). Gadjah Mada University Press, Yogyakarta.

Sarwono. 1995. Beternak Ayam Buras. Jakarta

Sexton ,T.J. and E.F. Giesen. 1982. Beltsville poultry semen extenderholdingturkey semen for six hours at $15^{\circ} \mathrm{C}$. J. Poultry Sci. 6:1202-1208

Solihati, N., Idi, R., Setiawan, R., Asmara, I. Y., \& Sujana, B. I. (2006). Pengaruh lama penyimpanan semen cair ayam buras pada suhu $5 \mathrm{C}$ terhadap periode fertil dan fertilitas sperma. J. Ilmu Ternak, 6(1), 7-1 Steel, P. G. D. And J. H. Torrie. 1991. Prinsip dan Prosedur Statistika Suatu Pendekatan Geometrik. Terjemahan B. Sumantri. PT Gramedia. Jakarta.

Sulandari, S., M.S. Zein, S. Paryanti, dan T. Sartika. 2007. Taksonomi dan asal usul ayam domestikasi. Hlm. 5-20. Dalam K. Diwyan-to dan S.N. Prijono (Ed.).keanekaragamanSumber Daya Hayati Ayam Lokal Indonesia : manfaat dan potensi. Pusat PenelitianBiologi, Lambang Ilmu Pengetahuan Indonesia, Bogor.

Steel, P. G. D. And J. H. Torrie. 1991. Prinsip dan Prosedur Statistika Suatu Pendekatan Geometrik. Terjemahan B. Sumantri. PT Gramedia. Jakarta.

Sulisbury, G. W. dan N. L. Van Demark. 1985. Fisiologi Reproduksi Dan Insiminasi Buatan Pada Sapi. Terjemahan R. Djanuar. Fakultas Peternakan Universitas Gajamada. Yogyakarta

Susilawati, T 2011. Spermatozoatology. Universitas Briwijaya Pres. Malang. ISBN: 978-602-8960-04-05.

Sarengat, W. 1982. Pengantar Ilmu Ternak Unggas. Fakultas Peternakan dan Perikanan Universitas Diponegoro. Semarang.

Srigandono, B. 1997. Produksi Unggas Air. Gadjah Mada University Press. Yogyakarta.

Sarwono, B. Berternak Ayam Buras. Jakarta: Penebar Swadaya,1995.

Sotiyono. 2001. Pengenalan Organ Reproduksi Ayam. Kerjasama antara PT. PERHUTANI (PERSERO), KPH Kendal dengan Forum Kelompok Sumber Daya Alam Jawa Tengah Pelestari. Semarang.

Syafar. 2001. Pengaruh Interval Waktu Penampungan terhadap Kualitas Semen Ayam Arab. Skripsi. Fakultas Peternakan. Universitas Brawijaya. Malang

Toelihere, M. R. 1985. Fisiologi Reproduksi pada Ternak. Angkasa, Bandung.

Toelihere, M. R. 1993. Insiminasi Buatan Pada Ternak Angkasa, Bandung.

Yaman, A. 2010. Ayam Kampung Unggul 6 Minggu Panen. Penebar Swadaya.

Wills, R.H.H., Lee, T.H., Graham, D., Mc. Glasson,W.B. and E.G. Hall. (1998). Postharvest. An Introduction to the Physiology and Handling of fruits and Vegetables. New South Wales University Press Ltd., Kensington : $105-107$ 